\title{
Removal and Effects of Surfactants in Activated Sludge System
}

\author{
DANIEL MITRU 1,2 , GHEORGHE NECHIFOR ${ }^{1}$, STEFANIA GHEORGHE ${ }^{2}$, ALINA ROXANA BANCIU ${ }^{2}$, \\ LUCIAN IONESCU ${ }^{2}$, CATALINA STOICA ${ }^{2}$, DANIELA LILIANA IONICA ${ }^{2}$, IRINA EUGENIA LUCACIU ${ }^{2 *}$ \\ 1"Politehnica" University of Bucharest, Faculty of Applied Chemistry and Materials Science, Department of Analytical \\ Chemistry and Environmental Engineering, no. 1-7, Polizu Str., 011061, Bucharest, Roumania \\ ${ }^{2}$ National Research and Development Institute for Industrial Ecology ECOIND Bucharest, 71-73 Drumul Podu \\ Dambovitei Str., 060652, Bucharest, Romania
}

The widespread use of detergents has raised concern with regard to the environmental pollution caused by their active substances, which are biorefractory, toxic or persistent. Even though anionic and non-ionic surfactants often used in commercial detergents composition are reasonably degradable under aerobic conditions and not particularly toxic at low concentrations, high concentration of surfactants influenced the activated sludge activity and are harmful for the aquatic environment. In the literature, data on the biodegradability and/or ecotoxicity of a certain type of surfactant (anionic, nonionic, cationic) are usually presented. Our study aimed to assess the biodegradability of a mixture of two types of surfactants (anionic mixed with non-ionic) and also, effects caused by their presence of elevated concentrations to the activated sludge microorganisms, within a batch experiment. We performed a biodegradability test (according ZahnWellens method) on 2 synthetic solutions with high concentrations of anionic surfactant -methyl dodecylbenzene sulfonate $(15-25 \mathrm{mg} / \mathrm{L})$ and non-ionic surfactant -4-nonylphenyl-polyethylene glycol $(10 \mathrm{mg} / \mathrm{L})$. The study established different percent of biodegradability (measured by COD decrease and surfactants removal) depending on initial concentrations of anionic and nonionic surfactants in the tested solutions. High surfactants concentrations modulated the activity and morphology of activated sludge, so its degradation efficiency of the organic substrate has decreased. Surfactant solutions resulting from biodegradability experiment have been tested for toxicity to planktonic crustaceans (Daphnia magna).

Keywords: anionic surfactants, non-ionic surfactants, COD, activated sludge, flocs morphology

Surfactants (also called surface-active agents) are a wide group of chemical compounds which have a large number of applications due to their solubility properties, detergency, endurance of water hardness, as well as emulsifying, dispersing and wetting properties. They have numerous applications in humans lives, being used in household cleaning detergents, personal-care products, textiles, paints, polymers, pesticides, pharmaceuticals, mining, oil recovery, pulp and paper industries, coatings and processing aids [1].

The worldwide usages of surfactants have constantly increased, from 1.7 million tons in 1984 to 15.93 million tons in 2014. In 2022 it is expected to reach 24.19 million tons [2].

Due to chemical structures, the surfactants can be classified as ionic or non-ionic, depending on the nature of the hydrophilic group [3].

Anionic surfactants represent the major class of surfactants used in detergents and cleaning products and linear alkyl benzene sulfonates (LAS) are the most commonly used anionic surfactants. Even though LAS are 85-90\% aerobically degradable and not particularly toxic at low concentrations [4-6], high concentrations (more than $25 \mathrm{mg} / \mathrm{L}$ ) of this surfactant in wastewater plants can damage the operation and performance due the foam formation and biological toxicity. Concentration of LAS $\geq 100 \mathrm{mg} / \mathrm{L}$ in activated sludge systems increased the inhibition of the sludge degradation capacity, which results in elevated values of organic matter (measured as COD) in the effluent [7]. The surfactants spread in the aquatic systems, especially LAS could damage fish grills triggering excessive mucus secretion and also a decreased respiration rate in the common goby [8].

Alkylphenol Ethoxylates (APEs) are the most used type of nonionic surfactants in a wide variety of industrial applications and consumer products. The most used commercial APEs are Octylphenol Ethoxylates (OPEs) and Nonylphenol Ethoxylates (NPEs) [9, 10]. Many research studies reported that NPEs removal in wastewater treatment plants (WWTPs) was from 93 to 99\% [11], but the degradation metabolites were more toxic than the parent surfactants [12-14]. The literature concerning the toxicity of specific surfactants focused on their persistence in the aquatic environment and their bioaccumulative nature to aquatic organisms, while the effect of the presence of different surfactants on the performance of activated sludge processes received less attention $[10,15,16]$.

*email:irina.lucaciu@incdecoind.ro/bioteste.ecoind@gmail.com 
During wastewater treatment, especially in the biological process of activated sludge, surfactants are partially aerobically broken down and partially adsorbed on sewage sludge flocs. It has been reported that high concentrations of anionic and nonionic surfactants have a negative influence on sludge flock properties [17, 18] and can lead to microorganism's cell degradation [16,17]. The adsorption of surfactants can modify the characteristics of activated sludge flocs morphology and furthermore, surfactants supplied to the sludge interact with carbohydrates and peptides, which may reduce the degradation pattern of these compounds $[17,19,20]$. Therefore, the fate of surfactants, and particularly their decomposition in activated sludge processes, plays an important role in minimizing environmental impact.

Due to detergents / cleaning products huge consumptions, as well as their complex mixtures of substances and different formulations, the evaluation of surfactants biodegradability and potential toxicity to ecosystems has become a crucial topic in science and policy, in accordance with European Regulations (EC 648/2004; EC 907/2006; EC 1336/2008; EC 1272/2008) [21].

The main goal of the present study was to assess the removal of both anionic and non-ionic surfactants from the activated sludge's system, taking into account biodegradability and aquatic toxicity. Laboratory experiment carried out according to the Zahn-Wellens method [22]. The biodegradability level (measured as COD \%) and the effect on activated sludge biomass and flocs morphology of a mixture containing anionic and nonionic surfactant at increased concentrations were evaluated. Solutions resulting from biodegradation have been tested to estimate the acute toxicity to planktonic crustaceans (Daphnia magna), because these aquatic organisms are indicated to be most sensitive to the effects generated by the anionic and non-ionic surfactants, first after the luminescent bacterium Vibrio fischeri [23].

\section{Experimental part \\ Materials}

Activated sludge samples used in biological experiments were taken from a municipal wastewater treatment plant (WWTP). The samples were collected from aeration basin and the biodegradability tests were performed on the same day of sample collection.

The surfactants used in the experiments were: commercial methyl dodecyl benzene sulfonate (MDBS), with purity of $101 \%$ (Merck Chemicals Company) as anionic surfactant and 4-nonylphenyl-polyethylene glycol (PGN), with purity of $95 \%$ (Sigma-Aldrich Chemie $\mathrm{GmbH}$ ) as nonionic surfactant.

Two stock surfactants solutions in distilled water were prepared: anionic surfactant solution- $500 \mathrm{mg} / \mathrm{L} \mathrm{MDBS}$ and $400 \mathrm{mg} / \mathrm{L}$ PGN. Experimental solutions (15-25 mg/L anionic surfactant mixed with $10 \mathrm{mg} / \mathrm{L}$ nonionic surfactant) were prepared from the stock solution, using synthetic nutrient medium, specific to the biodegradability method applied to assess the removal and the effect of surfactants on activated sludge microorganisms.

\section{Analytical methods}

The anionic surfactant was determined according to the methylene blue active substance-MBAS method (standard SR EN 903:2003), while the nonionic surfactant was analyzed by the method of bismuth active substance-BiAS method (standard SR ISO 7875-2:1996).

In MBAS method, methyl dodecylbezene sulfonate in reaction with methylene blue formed ion pairs which are extracted in chloroform and determined spectrophotometrically at $650 \mathrm{~nm}$ [24].

The BiAS procedure consists of gas-stripping of non-ionic surfactants from liquid sample to an ethyl acetate layer, evaporation of ethyl acetate, dissolution of the residue in a water/methanol mixture, precipitation of ethoxylates with Dragendorff reagent, filtration and washing of the precipitate with glacial acetic acid, dissolution of the precipitate in sodium tartrate solution and determination of bismuth UV spectrophotometrically at $263.5 \mathrm{~nm}$ [25].

Colorimetric analysis of surfactants was performed using the spectrophotometer Specord BU 205 (Analytic Jena, Germany).

\section{Testing methods}

To assess the biodegradability of a mixture of two types of surfactants (MDBS mixed with PGN), a standardized method for the evaluation of ultimate aerobic biodegradability - SR EN ISO 9888:2004 (Zahn Wellens test) was applied [22].

Zahn-Wellens test was performed on 2 experimental solutions, prepared so that the initial concentrations of surfactants in the test mixtures were: $15 \mathrm{mg} / \mathrm{L}$ of MDBS and $10 \mathrm{mg} / \mathrm{L}$ of PGN (mixture A) and respectively, $25 \mathrm{mg} / \mathrm{L}$ of MDBS and $10 \mathrm{mg} / \mathrm{L}$ of PGN (mixture B). Appropriate volumes of the surfactants stock solutions (500 mg/L MBDS and $400 \mathrm{mg} / \mathrm{L} \mathrm{PGN}$ ) were dissolved in nutrient medium consisted of: $\mathrm{KH}_{2} \mathrm{PO}_{4}, 85 \mathrm{mg} / \mathrm{L}, \mathrm{K}_{2} \mathrm{HPO}_{4}, 217.5 \mathrm{mg} / \mathrm{L}$, $\mathrm{Na}_{2} \mathrm{HPO}_{4}, 334 \mathrm{mg} / \mathrm{L}, \mathrm{NH}_{4} \mathrm{Cl}, 5 \mathrm{mg} / \mathrm{L}, \mathrm{MgSO} 4 \times 7 \mathrm{H} 2 \mathrm{O}, 22.5 \mathrm{mg} / \mathrm{L}, \mathrm{CaCl} 2 \times 2 \mathrm{H} 2 \mathrm{O}, 36.4 \mathrm{mg} / \mathrm{L}, \mathrm{FeCl} 3 \times 6 \mathrm{H} 2 \mathrm{O}, 0.25 \mathrm{mg} / \mathrm{L}$. Each solution (A and $\mathrm{B}$ ) was inoculated with activated sludge suspension, to obtain small no of microorganisms in the test mixture $\left(10^{4}-10^{6} \mathrm{CFU} / \mathrm{cm}^{3}\right)$. 
The biodegradability experiment was conducted in batch activated sludge system using 3 bubbling stirred reactors : 2 test reactors contained surfactants solutions: A and respectively, solution B and the control reactor containing similar quantities of nutrient medium and active sludge suspension, without addition of any surfactant.

The biodegradation process is monitored by determination of Chemical Oxygen Demand (COD) in filtered samples, taken at regular time intervals. The percentage of ultimate biodegradation was calculated by measuring the decline in COD concentration of the tested mixtures, corrected for the blank, after each time interval (at least 4 occasions in the interval between the 1st and the last two days of the test run). Chemical oxygen demand (COD) was measured by a standard dichromatic method SR ISO 6060:1996 [26] and mixed liquor suspended solids in bioreactor were determined according to standard method SR EN 872:2005[27].

Additional information on the primary biodegradability and the total elimination of surfactant content by aerobic microorganisms, during the experimental period (21 days), was obtained.

The effect of mixture containing the both anionic and nonionic surfactants on activated sludge flocs and the quality of sludge biocenosis was also assessed using microscopic analysis of activated sludge collected from the 3 test reactors (A, B and control).

Acute static toxicity test on the liquors deriving from biodegradation test was conducted with planktonic crustacean (Daphnia magna), using DaphToxkitF $F^{T M}$ bioassay [28] and the method described in Daphnia sp. Acute Immobilization Test (OECD 202 and SR EN ISO 6341:2013) [29, 30]. The biological material used was planktonic crustaceans, Daphnia magna species, provided by MicroBioTests Inc. (Belgium) as immobilized preparation - ephippia (strain batch no. DM131218, expired on 31.07.2019).

Prior to start the toxicity test, Daphnia magna ephippia were incubated for three days at $20-22^{\circ} \mathrm{C}$ and a light intensity of 6000 lux. Daphnia neonates were exposed to a dilution series of both biodegradation surfactants mixtures (A1, B1: $100 \%, \mathrm{~A} 2, \mathrm{~B} 2: 50 \%, \mathrm{~A} 3, \mathrm{~B} 3: 25 \%)$ for a period of 48 hours. In parallel with the experimental test solutions, inhibition tests were also carried out for the control sample (nutrient medium + crustaceans, without surfactants). 20 animals, divided into four groups of five animals each, were used at each test concentration and for the control. Bioassay was performed under static conditions, at $20 \pm 1^{\circ} \mathrm{C}$, with a daily light: dark period of 12:12 hours and there was no feeding and no aeration during the test. The endpoint of the test was immobilization and / or mortality of crustaceans (determined visually after 24 and 48 hours) and the number of immobile specimen, out of 20, was recorded after 48 hours incubation time and compared with control values. Four replicates of each dilution were tested. The results were analyzed in order to calculate the mobility inhibition of 50\% of Daphnia population (effective concentration $\mathrm{EC}_{50}$ at $48 \mathrm{~h}$ ).

The MBT Daphnia Regetox 2.0 software (Microbiotests Inc., Belgium) was used for experimental data interpretation.

\section{Results and discussions}

\section{Biodegradation test (Zahn-Wellens method)}

Current legislation regulates surfactants (anionic and nonionic) concentrations at the entrance to the urban waste water treatment plants $(25 \mathrm{mg} / \mathrm{l})$ and maximum concentrations that can be discharged into the aquatic environment $(0.5 \mathrm{mg} / \mathrm{l})$.

Taking into account these legislative requirements, two nutrient solutions with increased content of surfactants (25 $\mathrm{mg} / \mathrm{L}$ and $35 \mathrm{mg} \mathrm{L}$, respectively) were studied to assess the biodegradation and removal of anionic and non-ionic surfactants by aerobic microorganisms from activated sludge.

The results obtained within surfactants and control biodegradation test (Table 1) show that biodegradability is influenced by the initial concentration of surfactants; the degree of biodegradation (expressed as \% COD) is higher (above $90 \%$ ) when the initial total surfactant concentration is $25 \mathrm{mg} / \mathrm{L}(15 \mathrm{mg} / \mathrm{L}$ - anionic $+10 \mathrm{mg} / \mathrm{L}-$ nonionic). When the initial total surfactant concentration is $35 \mathrm{mg} / \mathrm{L}(25 \mathrm{mg} / \mathrm{L}-$ anionic $+10 \mathrm{mg} / \mathrm{L}-$ nonionic), the degree of biodegradation achieved (\% COD) is lower $80 \%$. The percentage COD biodegradation was plotted against time for both solutions A and B, to give the biodegradation curve (Fig. 1).

Table 1

THE RESULTS OF ULTIMATE BIODEGRADABILITY (COD ELIMINATION) - ZAHN WELLENS TEST

\begin{tabular}{|c|c|c|c|c|}
\hline \multirow{2}{*}{ Time (day) } & \multicolumn{2}{|c|}{ Mixture A } & \multicolumn{2}{c|}{ Mixture B } \\
\cline { 2 - 5 } & Net-COD* $\left(\mathrm{mgO}_{2} / \mathrm{L}\right)$ & $\begin{array}{c}\text { COD Removal } \\
\text { Efficiency }(\%)\end{array}$ & $\begin{array}{c}\text { Net-COD* } \\
\left(\mathrm{mgO}_{2} / \mathrm{L}\right)\end{array}$ & $\begin{array}{c}\text { COD Removal } \\
\text { Efficiency }(\%)\end{array}$ \\
\hline $\begin{array}{c}\text { Value at the beginning } \\
\text { of test } \\
(0 \mathrm{~h})\end{array}$ & 2912 & - & 4292 & \\
\hline 1 & 2643 & 9 & 3816 & 37 \\
\hline 3 & 1332 & 54 & 2708 & 56 \\
\hline 7 & 835 & 71 & 2008 & 69 \\
\hline 10 & 506 & 82.6 & 1332 & \\
\hline
\end{tabular}




\begin{tabular}{|c|c|c|c|c|}
\hline 14 & 374 & 87 & 1133 & 73.6 \\
\hline 17 & 155 & 94.7 & 998 & 76.75 \\
\hline 20 & 142 & 95.1 & 990.8 & 76.9 \\
\hline 21 & 140 & $\mathbf{9 5 . 2}$ & 984 & $\mathbf{7 7}$ \\
\hline
\end{tabular}

*Net-COD = COD-Mixture - COD-Blank

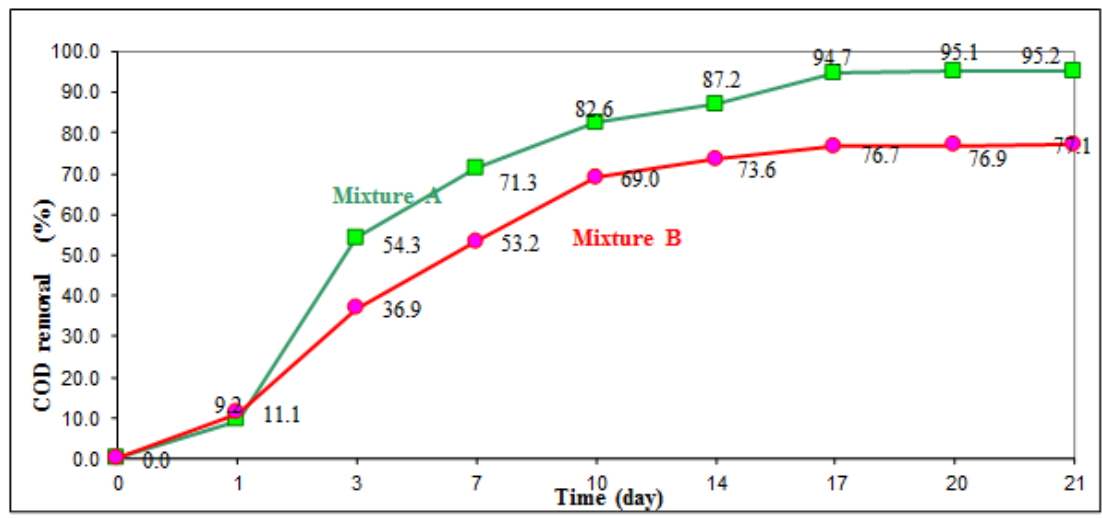

Fig. 1. Biodegradation Curve (Zahnn-Wellens Test) COD removal efficiency with the time in solutions A and B

Biodegradation should be considered to have started when it exceeds the $10 \%$ level.

A high biodegradation level (>80\%) was reached after 10-12 days by mixture A (total initial content of anionic and nonionic surfactants: $25 \mathrm{mg} / \mathrm{L}$ ), while for mixture B (total initial content of anionic and nonionic surfactants: 35 $\mathrm{mg} / \mathrm{L}$ ), the maximum biodegradability level was $77 \%$ after 21 days of experiment. Lag period was less than 3 days for mixture A and about 5-6 days for mixture B and time to reach pass level (70\% COD removal) was 14 days for mixture $\mathrm{A}$ and 16-18 days for mixture $\mathrm{B}$. At the end of experimental period the degree of biodegradation, calculated as COD removal, was higher than $70 \%$ for both solutions A and B.

The percentage of COD removal $\geq 70 \%$ means that the substance could be 'ultimately' biodegradable, while the percentage $<70 \%$ and $\geq 20 \%$, the substance is 'inherently' biodegradable. Besides of the $70 \%$ pass level, also the criteria for removing surfactant content of at least $80 \%$ must to be achieved.

Similar with results obtained for COD elimination, the surfactants removal (Table 2) during experimental period (21 days) was higher for mixture A (86\% removal of total content of surfactants) comparative with mixture B, where removal was less than $80 \%$, which represents a minimum level of primary biodegradability for surfactants, according to European Regulation No 648/2004 [31].

Table 2

THE RESULTS OF PRIMARY BIODEGRADABILITY (ANIONIC AND NONIONIC SURFACTANTS REMOVAL) - ZAHN WELLENS TEST

\begin{tabular}{|c|c|c|c|c|c|c|}
\hline \multirow{2}{*}{ Day no. } & \multicolumn{3}{|c|}{ Mixture A - removal of surfactants (\%) } & \multicolumn{2}{c|}{ Mixture B - removal of surfactants (\%) } \\
\cline { 2 - 7 } & $\begin{array}{c}\text { Anionic } \\
\text { surfactant }\end{array}$ & $\begin{array}{c}\text { Nonionic } \\
\text { surfactant }\end{array}$ & $\begin{array}{c}\text { Total content } \\
\text { of surfactants }\end{array}$ & $\begin{array}{c}\text { Anionic } \\
\text { surfactant }\end{array}$ & $\begin{array}{c}\text { Nonionic } \\
\text { surfactant }\end{array}$ & $\begin{array}{c}\text { Total content } \\
\text { of surfactants }\end{array}$ \\
\hline 1 & 15 & 6.4 & 11.7 & 13 & 15 & 14 \\
\hline 3 & 38.6 & 28 & 34.4 & 38.6 & 22 & 33 \\
\hline 7 & 60 & 41.5 & 53 & 56 & 30.6 & 48 \\
\hline 10 & 76 & 59 & 69.5 & 65 & 45 & 59 \\
\hline 14 & 82 & 76 & 80 & 72 & 62 & 68.8 \\
\hline 17 & 87 & 80.3 & 84.6 & 76 & 65.7 & 73 \\
\hline 21 & 89.67 & 84.8 & 87.77 & 77.5 & 68 & 74.55 \\
\hline
\end{tabular}

The values of COD and surfactants removal obtained within Zahn-Wellens test indicated that biodegradation process occurred at concentration of $25 \mathrm{mg} / \mathrm{L}$ anionic surfactant, mixed with $10 \mathrm{mg} / \mathrm{L}$ non-ionic surfactant and this mixture may be considered readily biodegradable in the aquatic environment. Comparing the COD removal during the biodegradability test versus surfactants concentrations from tested mixtures, it can be appreciated that concentration of anionic surfactant greater than $25 \mathrm{mg} / \mathrm{L}$ mixed with non-ionic surfactant greater than $10 \mathrm{mg} / \mathrm{L}$ might inhibit the substrate uptake and also, affected the process of biodegradation with activated sludge.

At the end of the biodegradability test, analyzes of surfactants concentrations adsorbed on the activated sludge were performed. Total content of surfactants was less than $1 \mathrm{mg} / \mathrm{L}(0.36 \mathrm{mg} / \mathrm{L}$ - anionic surfactant and $0.58-$ nonionic surfactant) for mixture A, while for mixture B were determined concentrations of $1.77 \mathrm{mg} / \mathrm{L}$ anionic surfactant and $0.83 \mathrm{mg} / \mathrm{L}$ nonionic surfactant.

The effect of surfactants (MDBS and PGN) on the morphology of activated sludge used as inoculum in the biodegradability test was analyzed via microscopic study. 
Microscopic examination of activated sludge collected from experimental mixtures allowed the assessment of activated sludge biocenosis. The microorganisms found were mainly Gram-negative organisms (Klebsiella pneumoniae, Raoultella planticola, Pseudomonas, Vorticella), suggesting that they are more tolerant to the surfactant concentrations present in the solutions than the Gram-positive organisms. It has been reported by Higgins and Burns [32] that many Gram-positive bacteria are noticeably affected by surfactant concentrations of 10-20 ppm while several thousand ppm may be without effect on Gram-negative organisms.

Microscopic examination confirmed changes in the morphology and flocs of activated sludge caused by high loads of surfactants in tested mixture $(25 \mathrm{mg} / \mathrm{L}$ MDBS and $10 \mathrm{mg} / \mathrm{L}$ PGN). The vitality and morphology of protozoa highlighted in the blank control was substantial changed by the presence of surfactants and formation of cysts was observed. High concentration of surfactants exerted obvious effect also, to the quality and quantity of filamentous and non-filamentous bacteria observed in sludge from blank control (Fig. 2). Formation of cysts and lysis of cellular walls, as well as total cell damage observed in microscopic images (Fig.2b, c), particularly for solution B, represent type of a defensive response by protozoa to hazardous environmental conditions, in order to survive. Microscopic observation also showed that activated sludge flocs were disintegrated / fragmented, became smaller and some of cells were damaged, in particular anionic surfactant at concentrations of $25 \mathrm{mg} / \mathrm{L}$ in mixture with non-ionic surfactant in conc.de $10 \mathrm{mg} / \mathrm{L}$ (Fig. 2c).

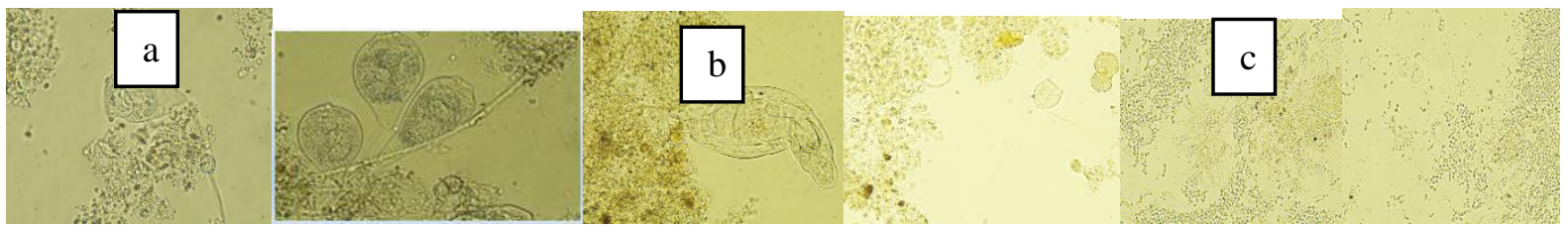

Fig.2. Microscopic images of activated sludge (magnification 400x) at the end of biodegradability test;

a) sludge sample-blank control; b) sludge sample-solution A (25mg/L surfactants); c) sludge sample-solution B (35mg/L surfactants)

Surfactant solutions obtained at the end of the biodegradability experiment were subjected to an acute planktonic crustacean toxicity test - Daphnia sp. Acute Immobilization Test.

Results on immobilization and / or death of organisms recorded after $24 \mathrm{~h}$ and $48 \mathrm{~h}$ for each tested solution constituted the basis for calculating the percentage of inhibition effect (no. of dead bodies + no. of immovable organisms) $/ 20 \times 100=\%$.

Results are summarized in Table 3, showing for each test solution and control the immobilization /mortality effect after 24 and 48 hours exposure time.

Table 3

THE TOXIC EFFECTS GENERATED BY SURFACTANTS SOLUTIONS OBTAINED AFTER BIODEGRADABILITY TEST ON DAPHNIA MAGNA

\begin{tabular}{|l|c|c|}
\hline \multirow{2}{*}{ Tested solutions } & \multicolumn{2}{|c|}{$\begin{array}{c}\text { Immobilization /mortaly effect (\%) } \\
\text { daphnia }\end{array}$} \\
\cline { 2 - 3 } & $24 \mathrm{~h}$ & $\mathbf{4 8 h}$ (total) \\
\hline $\begin{array}{l}\text { Solution A1 (100\%) } \\
(1.55 \mathrm{mg} / \mathrm{L}-\text { anionic surfactant }+ \\
1.45 \mathrm{mg} / \mathrm{L} \text { nonionic surfactant) }\end{array}$ & 35 & 40 \\
\hline Solution A2 (50\%) & 0 & 0 \\
\hline Solution A3 (25\%) & 0 & 0 \\
\hline $\begin{array}{l}\text { Solution B1 (100\%) } \\
(5.35 \mathrm{mg} / \mathrm{L}-\text { anionic surfactant }+ \\
3.43 \mathrm{mg} / \mathrm{L} \text { nonionic surfactant) }\end{array}$ & 85 & 100 \\
\hline Solution B2 (50\%) & 35 & 80 \\
\hline Solution B3 (25\%) & 0 & 10 \\
\hline $\begin{array}{l}\text { Control sample } \\
\text { (nutrient medium + crustaceans) }\end{array}$ & 0 & 0 \\
\hline
\end{tabular}

The acute toxic concentration value - effective concentration $\left(\mathrm{EC}_{50-48 \mathrm{~h}}\right)$ was estimated for biodegradability effluent - mixture B, based on the linear regression between the mortality / immobilization percentages and the tested concentrations (fig. 3). The concentration $\left(\mathrm{EC}_{50-48 \mathrm{~h}}\right)$ with immobility/mortality effect for $50 \%$ of the total number of Daphnia magna organisms used in the acute toxicity experiment was estimated using MBT Daphnia Regetox 2.0 software (Microbiotests Inc., Belgium). 


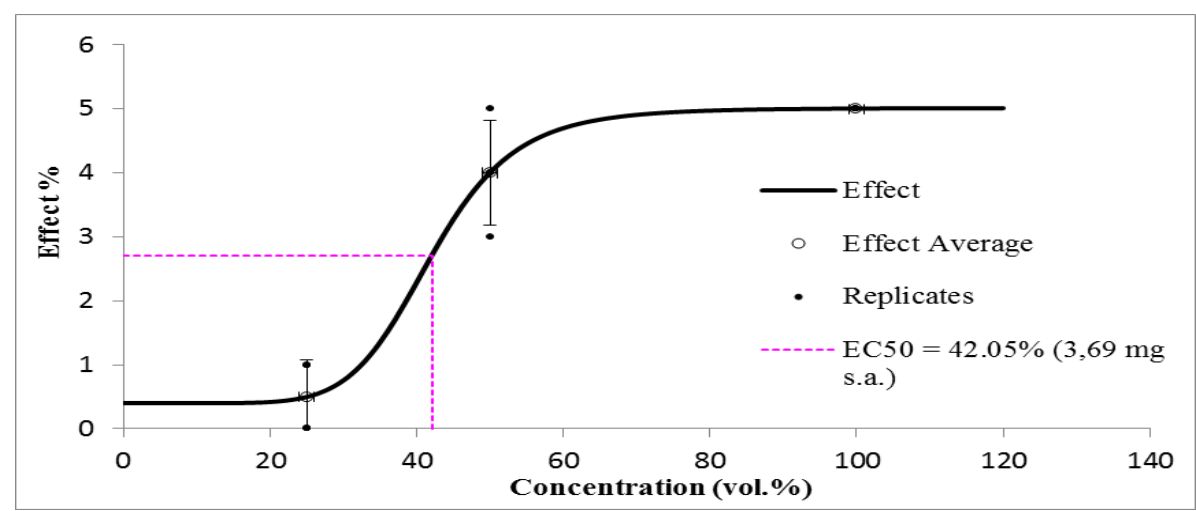

Fig.3. Estimation of EC50 (48h) - Daphnia magna - Mixture B

The concentration $\mathrm{EC}_{50-48 \mathrm{~h}}$ about $42.05 \%$ dilution of biodegradability effluent (mixture B) represents a total content of anionic and nonionic surfactants of $3.69 \mathrm{mg} / \mathrm{L}$. According to toxicity classification system of effluents discharged into aquatic environment $[33,34]$, the toxicity of surfactants mixture could be correlated with 25 toxicity units, that suppose an acute toxicity for Daphnia magna (Class III). The final aquatic effect could be magnified or reduce depending on WWTP efficiency, water dilution, and also by biotic (aquatic microbial communities) and abiotic factors (physical and chemical structure of aquatic matrices). Also, other aquatic representative species such as algae or fish can highlight different effects leading to a changed toxicity diagnostic [35].

The mean acute lethal concentration was not estimated for mixture A, because the inhibition / mortality percentage was below 50\%. Based on the results obtained, it can be appreciated that the mixture A in 50\% dilution (total concentration of surfactants less than or equal to $1.5 \mathrm{mg} / \mathrm{L} ; 0.775 \mathrm{mg} / \mathrm{L}$ anionic $+0.725 \mathrm{mg} / \mathrm{L}$ nonionic) present no acute toxic effects for planktonic crustacean (Daphnia magna).

\section{Conclusions}

Commercial anionic and nonionic surfactants (methyl dodecyl benzene sulfonate - MDBS and 4-nonylphenylpolyethylene glycol - PGN), often used as active substances in detergents and cleaning products were examined in this study to assess their biodegradability in activated sludge`s aerobic system and to investigate their effect on activated sludge biomass and flocs morphology. Also, solutions resulting from biodegradation have been tested to estimate the acute toxicity to planktonic crustaceans (Daphnia magna. The following conclusions can be made on the basis of results obtained within Zahn-Wellens test and ecotoxicity test with Daphnia magna:

i) Mixture of MDBS surfactant in concentration up to $15 \mathrm{mg} / \mathrm{L}$ with PGN surfactant in concentration up to 10 $\mathrm{mg} / \mathrm{L}$ can be considered readily biodegradable and may not pose a hazard to the aquatic environment. The COD removal and surfactants degradation exceeded the pass level for ready biodegradability, according to testing method, OECD criteria and European Regulation No 648/2004 on Detergents requirements. The sludge microorganisms adapted to the test substrate and a plateau of more than $80 \%$ biodegradation was reached within 21 days of batch experiment;

ii) Mixture of MDBS surfactant in concentration of $25 \mathrm{mg} / \mathrm{L}$ with PGN surfactant in concentration of $10 \mathrm{mg} / \mathrm{L}$ reached the pass level for COD removal $(\geq 70 \%)$, but the total surfactant decrease was less than $80 \%$. The increased concentrations of surfactants have been affected biocenosis and active sludge morphology, causing fragmentation of flocs and lysis of protozoa cells;

iii) Acute toxicity value estimated to the aquatic organism tested (planktonic crustacean - Daphnia magna) was $3.69 \mathrm{mg} / \mathrm{L}$ - total content of surfactants $(2.25 \mathrm{mg} / \mathrm{L}$ - anionic surfactant and $1.44 \mathrm{mg} / \mathrm{L}$ - nonionic surfactant. The mixture of anionic and non-ionic surfactants in concentration $\leq 1.5 \mathrm{mg} / \mathrm{L}(0.775 \mathrm{mg} / \mathrm{L}$ anionic $+0.725 \mathrm{mg} / \mathrm{L}$ nonionic $)$ will not pose a hazard to the aquatic organisms.

We consider that a more accurate evaluation of the potential impact of anionic and nonionic surfactants mixture on aquatic environment requires a battery of tests to assess total degradation (mineralization), as well as ecotoxicological effects on different aquatic organisms. Our study will continue with new experiments to establish the effect of anionic and nonionic surfactants on activated sludge oxygen uptake rate and their environmental compatibility on the basis of ecological data.

Acknowledgements: The authors acknowledge the scientific and financial support offered by Politehnica University of Bucharest and National Research and Development Institute for Industrial Ecology - ECOIND Bucharest.

\section{References}

1. HAYES D. G., SMITH G., Biobased Surfactants (Second Edition): Synthesis, Properties and Applications, 2, no.1, 2019 , p. 3.

2. ROACH T.J., 2015, Anionic,Nonionc,Cationic, https://cleanfax.com/carpet-care/anionic-nonionic-cationic-what-do-they-all-mean/

3. HOLMBERG K, Handbook of Applied Surface and Colloid Chemistry, Chichester, Wiley, 2001

4. PASTEWSKI S., MEDRZYCKA K., Pol. J. Environ. Stud., 12, no.5, 2003, p.643. 
5. KARAHAN O., Bioresour. Technol., 101, 2010, p.92

6. GHEORGHE S, LUCACIU I, PASCU L, J. Environ. Prot. Ecol., 13, no. 1, 2012, p.155.

7. MACEDO T. Z.i, SILVA E. L., SAKAMATO I. K., ZAIAT M., VARESCHE M. B. A., Bioproc. Biosyst. Eng., 42, nr.6, 2019 , p. 1.

8. MUNGRAY A.K., KUMAR P., Elsevier, 63, no. 8, 2019, p. 981.

9. NAYLOR, C.G., J. Am. Oil Chem. Soc., 69, no.7, 1992, p. 695.

10.OTHMAN, M.Z., DING, L., JIAO, Y., Int. J. Chem. Mol. Eng., 3, no.10, 2009, p. 596.

11. NAYLOR, C.G., Text .Chem. Color., 27, no.4, 1995, p. 29.

12. AHEL, M., Wat. Res., 28, no.5, 1994, p.1131.

13. SCOTT, M.J., JONES, M.N., Biochimica et Biophysica Acta, 1508, 2000, p. 235.

14. GHEORGHE S, LUCACIU I, GRUMAZ R, STOICA C, J. Environ. Prot. Ecol., 13, no.2, 2012, p. 541.

15. GUTIERREZ, M., ETXEBARRIA, J. and FUENTES, L., Water Res., 36, 2002, p. 919.

16. OTHMAN, M.Z., DING, L., JIAO, Y., Int. J. Civil Environ. Eng., 2, no.4, 2010, p.196.

17. DERESZEWSKA A., CYTAWA S., TOMACZAK-WANDZEL R., MEDRZYCKA K., Pol. J. Environ. Stud., 24, no.1, 2015 , p.83.

18. LIWARSKA-BIZUKOJC, E., BIZUKOJC, M., Process Biochemistry, 40, 2005, p. 2067.

19. CSERHATI, T., FORGAACS, E., OROS, G., Environ. Int., 28, 2002, p.337.

20. JI,Z., CHEN,G., CHEN, Y., Bioresour. Technol., 101, 2010, p. 3457.

21. PEDRAZZANI, R., CERETTI, E., ZERBINI, I., CASALE, R., GOZIO, E., BERTANZA, G., GELATTI, U., DONATO, F., FERETTI, D., Ecotoxicol. Environ. Saf., 84, 2012, p. 274.

22. SR EN ISO 9888:2004 - Water quality - Evaluation of ultimate aerobic biodegradability of organic compounds in aqueous medium - Static test (Zahn-Wellens method)

23. LECHUGA, M., FERNÁNDEZ-SERRANO, M., JURADO, E., NÚÑEZ-OLEA, J., RÍOS, F., Ecotoxicol. Environ. Saf., 125, 2016 , p. 1.

24. SR EN 903:2003, Water quality - Determination of surfactants - Part 1: Determination of anionic surfactants by measurement of the methylene blue index (MBAS).

25.ISO 7875-2:1984, Water quality - Determination of surfactants - Part 2: Determination of non-ionic surfactants using Dragendorff reagent. 26. SR ISO 6060:1996 - Water quality - Determination of chemical oxygen demand.

27. SR EN 872:2005 - Water quality - Determination of the content of suspended solids. Filtration method on glass fiber filters

28. DAPHTOXKIT FTM: Crustacean Toxicity Screening Test for Freshwater. Standard Operational Procedure. MicroBioTest Inc. Belgium, www.microbiotests.be.

29. SR EN ISO6341:2013 - Water quality - Determination of the Inhibition of the Mobility of Daphnia magna Straus (Cladocera, Crustacea)

30. OECD Guidelines for Testing of Chemicals, Vol.1, Section 3, 1993, Paris, France

31. REGULATION (EC) No 648/2004 OF THE EUROPEAN PARLIAMENT AND OF THE COUNCIL on DETERGENTS

32. HIGGINS, I.J. and BURNS, R.G. The Chemistry and Microbiology of Pollution. VIII, 248 S., 130 Abb., 46 Tab. London-New York-San Francisco 1975: Academic Press

33. PERSOONE G., Environ. Toxicol., 18, no. 6, 2003, p. 395.

34. CRAIOVEANU, MG., GHEORGHE, S., LUCACIU, I., STOICA, L., CONSTANTIN, C., Rev. Chim. (Bucharest), 65, no.3, 2014 , p. 339.

35. MAURIZIO, C., GIOVANNI, L., HATICE, G., ANTONIETTA, S., LUIGI, R., MARCO, G., GIUSY, L., Process Saf. Environ., 124, 2019, p. 1.

$\overline{\text { Manuscript received: } 31.07 .2019}$ 
